\title{
CORRECTION
}

\section{Monitoring of radiologic disease activity by serum neurofilaments in}

MS

Neurol Neuroimmunol Neuroinflamm 0;8:e934. doi:10.1212/NXI.0000000000000934

In the article "Monitoring of radiologic disease activity by serum neurofilaments in MS" by Uher et al., ${ }^{1}$ the following sentence was omitted from the Study Funding statement: "The project was also funded by International Mobility of Researchers at Charles University (reg. $\mathrm{n}$. CZ.02.2.69/0.0/0.0/16_027/0008495) supported by the Operational Programme Research, Development and Education." The authors regret the error.

\section{Reference}

1. Uher T, Schaedelin S, Srpova B, et al. Monitoring of radiologic disease activity by serum neurofilaments in MS. Neurol Neuroimmunol Neuroinflamm 2020;7:e714. doi:10.1212/NXI.0000000000000714. 


\title{
Neurology \\ Neuroimmunology \& Neuroinflammation
}

\author{
Monitoring of radiologic disease activity by serum neurofilaments in MS \\ Neurol Neuroimmunol Neuroinflamm 2021;8; \\ DOI 10.1212/NXI.0000000000000934
}

This information is current as of November 25, 2020

\section{Updated Information \& \\ Services}

References

Permissions \& Licensing

Reprints including high resolution figures, can be found at:

http://nn.neurology.org/content/8/1/e934.full.html

This article cites 1 articles, 1 of which you can access for free at: http://nn.neurology.org/content/8/1/e934.full.html\#\#ref-list-1

Information about reproducing this article in parts (figures,tables) or in its entirety can be found online at:

http://nn.neurology.org/misc/about.xhtml\#permissions

Information about ordering reprints can be found online: http://nn.neurology.org/misc/addir.xhtml\#reprintsus

Neurol Neuroimmunol Neuroinflamm is an official journal of the American Academy of Neurology.

Published since April 2014, it is an open-access, online-only, continuous publication journal. Copyright $@$ 2020 American Academy of Neurology. All rights reserved. Online ISSN: 2332-7812.

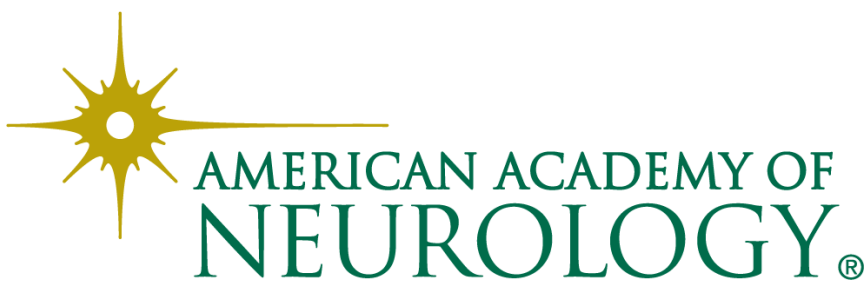

